Voltairomania. L'avocat Jean-Henri Marchand face à Voltaire. Textes réunis et présentés par AnneSophie Barrovecchio

\title{
Regina Bochenek-Franczakowa
}

\author{
(2) OpenEdition \\ Journals \\ Édition électronique \\ URL : http://journals.openedition.org/studifrancesi/33296 \\ DOI : 10.4000/studifrancesi.33296 \\ ISSN : 2421-5856 \\ Éditeur \\ Rosenberg \& Sellier \\ Édition imprimée \\ Date de publication : 1 décembre 2005 \\ Pagination : 651 \\ ISSN : 0039-2944

\section{Référence électronique} \\ Regina Bochenek-Franczakowa, « Voltairomania. L'avocat Jean-Henri Marchand face à Voltaire. Textes \\ réunis et présentés par Anne-Sophie Barrovecchio », Studi Francesi [En ligne], 147 (XLX | III) | 2005, mis \\ en ligne le 30 novembre 2015, consulté le 20 avril 2021. URL : http://journals.openedition.org/ \\ studifrancesi/33296; DOI : https://doi.org/10.4000/studifrancesi.33296
}

Ce document a été généré automatiquement le 20 avril 2021.

\section{cc) (†) $\odot$}

Studi Francesi è distribuita con Licenza Creative Commons Attribuzione - Non commerciale - Non opere derivate 4.0 Internazionale. 


\title{
Voltairomania. L'avocat Jean-Henri Marchand face à Voltaire. Textes réunis et présentés par Anne-Sophie Barrovecchio
}

\author{
Regina Bochenek-Franczakowa
}

\section{RÉFÉRENCE}

Voltairomania. L'avocat Jean-Henri Marchand face à Voltaire. Textes réunis et présentés par Anne-Sophie BARRovecchio, Publications de l'Université de Saint-Étienne, («Lire le DixHuitième siècle»), 2004, pp. 190.

1 «Voltairomania» est un néologisme judicieux, inventé par l'auteur de cette édition critique, qui caractérise à la fois l'œuvre présentée dans le volume, et le phénomène plus large, celui de l'énorme popularité de Voltaire - penseur et écrivain - parmi ses contemporains. Jean-Henri Marchand appartient à ce groupe d'auteurs mineurs du XVIII ${ }^{e}$ siècle qui ont voué une admiration sans bornes à l'égard du grand maître: mais cet «avocat oublié» se distingue parmi eux, par la fertilité et par l'effort de se distancer, à travers le pastiche et la moquerie. Jean-Henri Marchand était le maître de l'apocryphe et du pastiche; il publiait ses textes anonymement ou sous des prête-noms, dont certains étaient fameux (Monsieur André, perruquier). Écrivain qui adorait se déguiser et changer d'identité, il s'est essayé à tous les genres et styles, moins pour critiquer les écrits de ses contemporains que pour «créer des palimpsestes» (p. 12). L'auteur de cette édition a choisi quelques uns parmi la soixantaine des textes de Marchand, ceux notamment qui concernent Voltaire. On y trouve des vers et poèmes (Requête du curé de Fontenoy au roi; Épître à Ninon de l'Enclos et Réponse à M. De V***; Vers de Marchand sur Voltaire. Tirés des «Saisons»), une tragédie (Le Tremblement de terre à Lisbonne) et des pseudo-confessions en prose (Le Testament politique de Monsieur de $V^{* * *}$; Repentir ou Confession publique de Monsieur de Voltaire). Chaque œuvre est précédée d'une 
introduction et d'une bibliographie des manuscrits et éditions; parfois, l'auteur de l'édition joint des textes annexes, additions ou versions postérieures.

2 La lecture des textes de Jean-Henri Marchand permet d'entrevoir un aspect de la vie littéraire resté souvent dans l'ombre des études historiques et critiques: d'un côté, l'influence de la personnalité et de l'œuvre du «phare» des Lumières sur les auteurs d'une «production moyenne» de l'époque; de l'autre, le mythe voltairien en train de se former du vivant même du grand écrivain. L'exemple de Marchand peut aussi nous aider «à mieux évaluer l'originalité du style et de la pensée de Voltaire» (p. 17). 